\title{
Polycomb-Mediated Gene Silencing in Arabidopsis thaliana
}

\author{
Dong-Hwan Kim, and Sibum Sung*
}

\begin{abstract}
Polycomb group (PcG) proteins are conserved chromatin regulators involved in the control of key developmental programs in eukaryotes. They collectively provide the transcriptional memory unique to each cell identity by maintaining transcriptional states of developmental genes. PcG proteins form multi-protein complexes, known as Polycomb repressive complex 1 (PRC1) and Polycomb repressive complex 2 (PRC2). PRC1 and PRC2 contribute to the stable gene silencing in part through catalyzing covalent histone modifications. Components of PRC1 and PRC2 are well conserved from plants to animals. PcG-mediated gene silencing has been extensively investigated in efforts to understand molecular mechanisms underlying developmental programs in eukaryotes. Here, we describe our current knowledge on PcG-mediated gene repression which dictates developmental programs by dynamic layers of regulatory activities, with an emphasis given to the model plant Arabidopsis thaliana.
\end{abstract}

\section{INTRODUCTION}

In eukaryotes, DNA is packaged into a group of histone proteins to form nucleosome, the basic structural unit of chromatin. Dimers of four distinct histone proteins $(\mathrm{H} 2 \mathrm{~A}, \mathrm{H} 2 \mathrm{~B}, \mathrm{H} 3$, and $\mathrm{H} 4)$ constitutes the histone octamer that is a structural scaffold for nucleosome. Because DNA is tightly packaged in nucleosome and nucleosome often exists as higher-order chromosome structure, transcriptional regulation in eukaryotes requires elaborate transcriptional control machinery.

In most eukaryotes, a single cell (zygote) is produced after fertilization and develops into functionally and morphologically distinct multicellular tissues and organs through successive cell divisions and differentiation. Multicellular differentiation is achieved even though each uniquely differentiated cell contains exactly the same genome context. This genetically identical but

Department of Molecular Biosciences, Institute for Cellular and Molecular Biology, The University of Texas at Austin, Austin, TX 78712, USA

${ }^{*}$ Correspondence: sbsung@austin.utexas.edu

Received 12 September, 2014; accepted 15 September, 2014; published online 20 November, 2014

Keywords: chromatin looping, epigenetics, gene silencing, polycomb, trithorax functionally specialized cell fate is an output of differential transcriptional control in each cell lineage. It has long been a fundamental question in biology how a single cell can differentiate into functionally specialized cells in multicellular eukaryotes.

An earlier important clue arose from genetic study using Drosophila as a model organism. Homeotic genes in Drosophila determine body identities during development. Mutations in homeotic genes commonly result in various ectopic developments of body patterns (i. e., legs grow in the place of antennae) (Simon et al., 1992; Soto et al., 1995; Struhl and Akam, 1985). Subsequent genetic analyses in Drosophila unveiled a group of genes required for a proper control of such homeotic genes, and they are collectively called Polycomb group (PcG) genes (Lewis, 1978). PcG proteins participate in cell fate determination through their role in maintaining silent states of homeotic genes during development. In addition, homologs of PcG proteins have also been identified from plants and vertebrates, and mutations in these genes commonly resulted in homeotic mutations (Akasaka et al., 1996; Goodrich et al., 1997). Therefore, PcG proteins appear to be evolutionarily well conserved transcriptional regulators that are pivotal in key developmental programs.

In this review, we discuss recent advances in understanding on the function of PcG proteins during various developmental programs, with a focus given to Arabidopsis as a plant model system.

\section{POLYCOMB REPRESSIVE COMPLEXES IN ARABIDOPSIS}

PcG proteins form evolutionally conserved multi-protein complexes playing critical roles in the control of developmental processes in plants and other eukaryotes (Kim et al., 2009; Molitor and Shen, 2013). PcG-containing complexes are generally classified into two different groups of multi-protein complexes based on their biochemical properties; Polycomb repressive complex 2 (PRC2) and Polycomb repressive complex 1 (PRC1) (Margueron and Reinberg, 2011; Schatlowski et al., 2008). Both complexes are responsible for gene repression mainly through mediating covalent modifications of histone proteins, notably Histone $\mathrm{H} 3$ Lys 27 (H3K27) methylation by PRC2 and Histone H2A (H2A) ubiquitination by PRC1.

Polycomb repressive complex 2 (PRC2)

PcG genes were originally isolated from genetic screens in Drosophila that were designed to identify genes involved in controlling homeotic gene expression (Simon and Kingston, 2013). 
PRC2

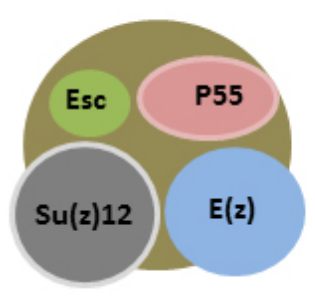

PRC1

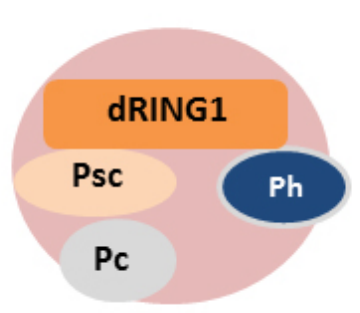

PRC1

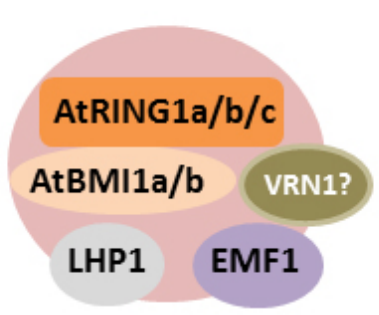

Fig. 1. Conserved components of PRC1 and PRC2 between Drosophila and Arabidopsis. Core components of Drosophila PRC2 and PRC1 (upper) and the homologous subunits found in Arabidopsis (bottom) were presented. Functional equivalents of $\mathrm{PcG}$ complex are indicated with the same color. EMF1 and VRN1 are plant-specific proteins in Arabidopsis PRC1-like complex.
PRC2

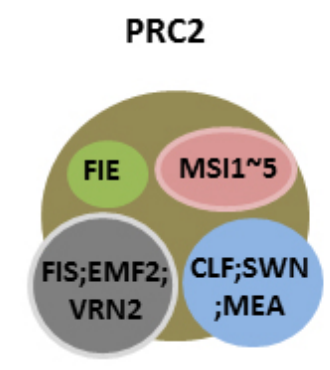

\section{Arabidopsis}

Studies using PcG proteins in Drosophila have served as a good model system to elucidate mechanistic details of PcG proteins in eukaryotes (Schwartz and Pirrotta, 2007; Simon and Kingston, 2009). Biochemical purification recognized four core components of PRC2 in Drosophila, Enhancer of zeste $(E(z))$, Extra sex combs (ESC), Suppressor of zeste 12 (Su(z)12), and Nucleosome-remodeling factor $55 \mathrm{kDa}$ subunit (Nurf55) (Czermin et al., 2002; Muller et al., 2002). These four subunits mediate histone methyltransferase (HMTase) activity of PRC2 on H3K27. Each subunit has a distinct role: $E(z)$ harbors a cataIytic Su(var)3-9, Enhancer-of-zeste and Trithorax (SET) domain for histone methylation; ESC enhances the catalytic activity of $\mathrm{E}(\mathrm{z}) ; \mathrm{Su}(\mathrm{z}) 12$ and Nurf55 are necessary for the nucleosome association (Cao et al., 2002) (Fig. 1). ESC is also able to bind to H3K27me3 histone mark, stabilizing and boosting the catalytic activity of PRC2. These coordinated activities of each PRC2 subunit reinforce self-propagation of H3K27me3 repressive marks at target chromatin during successive cell divisions and thus establishing stable chromatin contexts throughout mitosis (Margueron et al., 2009; Steffen and Ringrose, 2014).

All four core subunits of PRC2 exist in Arabidopsis. Homologs of Drosophila $E(z)$, the H3K27 methyltransferase, include CURLY LEAF (CLF), SWINGER (SWN), and MEDEA (MEA); Three homologs of Su(z)12 are EMBRYONIC FLOWER 2 (EMF2), VERNALIZATION 2 (VRN2), FERTILIZATION INDEPENDENT SEED 2 (FIS2). MULTI-SUBUNIT SUPPRESSOR OF IRA 1-5 (MSI1-5) are homologs of NURF55. FERTILIZATION INDEPENDENT ENDOSPERM (FIE) is a sole homolog of ESC. Detailed information on the components of Arabidopsis PRC2 is shown in Fig. 1.

In Arabidopsis, PRC2 complexes are grouped into three distinctive complexes largely based on three $\mathrm{Su}(\mathrm{z}) 12$ homologs (FIS2-PRC2, EMF2-PRC2, and VRN2-PRC2). MSI1 and FIE are constitutively expressed and thus serve as common subunits for all PRC2. On the other hand, expression of FIS2 and MEA are restricted in the female gametophyte and seed tissues, contributing to normal seed development (Kohler et al., 2003). For example, FIS2-PRC2 prohibits the endosperm formation in the absence of fertilization and represses endosperm proliferation after fertilization. EMF2-PRC2 notably contributes to the sporophytic development (i.e. floral organ). VRN2-PRC2 promotes floral transition in response to vernalization (long-term cold temperature) through the repression of a potent floral repressor, FLOWERING LOCUS C (FLC) in Arabidopsis (De Lucia et al., 2008; Kim et al., 2009). Many developmental genes are de-repressed in the mutants of PRC2 components, thus resulting in defects in various plant developmental programs, ranging from seed germination to floral transition (Kim et al., 2012; Muller and Goodrich, 2011). While FIS2-PRC2 controls proper development of endosperm (a part of seeds that does not develop further after germination), EMF2-PRC2 and VRN2PRC2 are essential for plant development. There are clear functional redundancies between components of EMF2-PRC2 and VRN2-PRC2. Genetic analysis demonstrated that VRN2 and EMF2 are functionallv redundant and so CLF and SWN are in Arabidopsis (Lafos et al., 2011; Tana et al., 2012). vrn2 emf2 or clf swn double mutants commonly exhibit undifferentiated embryo-like cell growth phenotypes (Chanvivattana et al., 2004; Schubert et al., 2005). Therefore, EMF2-PRC2 and VRN2PRC2 are essential for ensuring proper cell differentiation and growth during plant development (Chanvivattana et al., 2004; Makarevich et al., 2006; Schubert et al., 2005; Tang et al., 2012). It is, however, still not clear how these three PRC2 complexes exert cooperative and/or distinctive controls over developmental genes in time- and tissue-specific manners in plants.

Major function of PRC2 is to repress transcription through depositing repressive histone marks (i.e. H3K27me3) on target chromatin (He et al., 2013; Pien and Grossniklaus, 2007). Accumulation of H3K27me3 mark at chromatin is highly correlated with the level of gene repression. High-throughput genomic approaches have significantly improved our understanding on the importance of PRC2-mediated H3K27me3 in plant development. About 4,400 genes are marked with H3K27me3, which account for $17 \%$ annotated genes in Arabidopsis. H3K27me3 marks are mostly localized to individual genes in Arabidopsis, unlike in animals where $\mathrm{H} 3 \mathrm{~K} 27 \mathrm{me} 3$ is mainly enriched at heterochromatin region (Zhang et al., 2007). Interestingly, genome-wide profile of H3K27me3 mark is shown to be changed in time or tissue- 
dependent manners (Bouyer et al., 2011; He et al., 2012; Lafos et al., 2011; Roudier et al., 2011; Weinhofer et al., 2010). For example, H3K27me3-enriched loci are different in various tissues, such as shoot apical meristem (SAM), root, endosperm, and leaf tissues, indicating that H3K27me3 deposition is dynamically controlled during the development of different tissues.

\section{Polycomb repressive complex 1 (PRC1)}

The core subunits of PRC1 found in Drosophila are Posterior sex combs (Psc), drosophila RING (dRING), Polyhomeotic (Ph), and Polycomb (Pc) (Fig. 1). These are classified into two groups based on their biochemical function: One group (known as a writer group) has catalytic activity to mono-ubiquitinate histone $\mathrm{H} 2 \mathrm{~A}$ (Psc and dRING); the other group (known as a reader group) can recognize certain modified histone marks $(\mathrm{Pc})$. Mono-ubiquitination of $\mathrm{H} 2 \mathrm{~A}$ is mediated by Psc and dRING proteins that belong to a subfamily of E3 ubiquitin ligases. Classically, E3 ubiquitin ligases play a role in the degradation of protein through 26S proteasome machinery (Smalle and Vierstra, 2004). Unlike classical E3 ubiquitin ligases, E3 ubiquitin ligases, Psc and dRING, in PRC1 do not trigger 26S proteasome-mediated protein degradation. Instead, mono-ubiquitination of histone $\mathrm{H} 2 \mathrm{~A}$ (H2Aub1) results in transcriptional repression and chromatin compaction (Wang et al., 2004; Weake and Workman, 2008). In mammals, the ubiquitination activity of RING1B, a homolog of dRING, is strongly enhanced by the association with BMI1, a Psc homolog, through the RING-RING formation (Ben-Saadon et al., 2006; Buchwald et al., 2006; Cao et al., 2005).

In Arabidopsis, three homologs of Psc (AtBMI1a, AtBMlb, and AtBMI1c) and two homologs of dRING (AtRING1a and AtRING1b) have been identified (Sanchez-Pulido et al., 2008; $\mathrm{Xu}$ and Shen, 2008). Several studies have validated the enzymatic activity of these E3 ubiquitin ligases catalyzing H2Aub1 modification (Bratzel et al., 2010; Li et al., 2011; Yang et al., 2013). Therefore, the H2Aub1 modification appears to be a common mechanism by PRC1 in eukaryotes.

For example, levels of $\mathrm{H} 2 \mathrm{Aub} 1$ accumulation at PcG target genes, LEC1, FUS3, and STM, are significantly reduced in atring1a atring1b double mutants, despite that the levels of H3K27me3 accumulation remain unchanged (Bratzel et al., 2010; Xu and Shen, 2008). This indicates that PRC1 acts at the downstream of PRC2 and that H3K27me3 alone is to some extent not sufficient to trigger the silencing of common targets of PRC1 and PRC2. Similar result was also observed from the study of HOX gene regulation using embryonic stem cells (Cao et al., 2005; Eskeland et al., 2010). The reduction of H2Aub1 by knocking out of RING1B in mammalian cells caused the loss of HOX gene silencing while the level of H3K27me3 at HOX locus is not altered. Therefore, there is a clear epigenetic crosstalk between PRC1 and PRC2, and the coordinated function of two complexes are essential for the proper control of PcG target genes.

The second group (reader) in PRC1, Pc, physically links functional crosstalk between PRC2 and PRC1. Drosophila Pc protein contains $\mathrm{N}$-terminal chromo-domain (a chromatin binding domain) and C-terminal C-BOX domain (involved in PRC1 complex assembly) (Bardos et al., 2000). Especially, chromo-domain of $\mathrm{Pc}$ protein binds to $\mathrm{H} 3 \mathrm{~K} 27 \mathrm{me} 3$ histone mark, which is catalyzed by PRC2 (Bernstein et al., 2006b; Min et al., 2003). Therefore, the histone binding activity of Pc contributes to the physical link between PRC2 and PRC1.

Although E3 ubiquitin ligases (Psc and dRING) are well conserved across many eukaryotes, no apparent homolog of either $\mathrm{Pc}$ or $\mathrm{Ph}$ is found based on sequence homology in Arabidopsis genome. However, several functional equivalents of Drosophila
Pc have been identified in Arabidopsis. One of them is a chromo-domain protein, LIKE-HETEROCHROMATIN PROTEIN (LHP1)/ TERMINAL FLOWER2 (TFL2) (Mylne et al., 2006; Sung et al., 2006). Like Pc in Drosophila, LHP1 harbors a chromo-domain at its N-terminal region. LHP1 displays the binding specificity to H3K27me3 histone mark through its chromodomain (Exner et al., 2009). In addition, a genome-wide analysis of LHP1 showed that LHP1-enriched loci are highly overlapped with H3K27me3 enriched loci (Turck et al., 2007; Zhang et al., 2007). Another characteristic of LHP1 as a functional equivalent of Pc is that LHP1 physically interacts with AtRING1a, a component of PRC1 (Xu and Shen, 2008). Taken together, these data support the idea that LHP1 plays a role, similar to Drosophila Pc, as a reader component of PRC1 and forms a PRC1-like complex with AtRING1 and AtBMI1 proteins in Arabidopsis. Up to date, however, no functional homolog of $\mathrm{Ph}$ has been identified in Arabidopsis. Detailed information of components of PRC1 are shown in Fig. 1.

Two DNA-binding proteins, EMBRYONIC FLOWER1 (EMF1) and REDUCED VERNALIZATION RESPONSE 1 (VRN1) appear to function as components of PRC1 in Arabidopsis (Aubert et al., 2001; Calonje et al., 2008; Levy et al., 2002). Lesions in EMF1 resulted in pleiotropic phenotypes similar to mutants in PcG genes (Kim et al., 2012; Moon et al., 2003). EMF1 interacts with AtRING1a/1b and AtBMl1a/1b proteins in vitro and is required for proper $\mathrm{H} 2 \mathrm{Aub} 1$ modification at PRC1 target chromatin (Bratzel et al., 2010). In vitro biochemical assay showed that EMF1 binds to DNA and inhibits the chromatin remodeling similar to the activity of Drosophila Psc (Beh et al., 2012; Calonje et al., 2008). A genomic-wide mapping using chromatinimmunoprecipitation (ChIP) followed by tiling-microarray analysis showed that EMF1 is highly enriched at loci marked with H3K27me3 (Kim et al., 2012). Therefore, it is likely that EMF1 is a component of PRC1 and cooperates with PRC2 through H3K27me3 histone mark. Because EMF1 does not show any sequence similarity with known functional domains of proteins, mechanistic details on how EMF1 exerts its function in Arabidopsis remain elusive. A B3-domain protein, VRN1 was identified from vernalization mutant screening in Arabidopsis (Levy et al., 2002). VRN1 is essential for the stable repression of the floral repressor, $F L C$, in response to vernalization, long-term cold. In vrn1 mutants, a repressive histone mark, H3K9me2 fails to accumulate at FLC, but $\mathrm{H} 3 \mathrm{~K} 27 \mathrm{me} 3$ is normally enriched at FLC in vernalization, indicating that VRN1 is associated with $\mathrm{H} 3 \mathrm{~K} 9$ methylation at FLC (Bastow et al., 2004; Sung and Amasino, 2004). VRN1 binds to DNA in a non-sequence specific manner (Levy et al., 2002). It is unknown how VRN1 specifically participates in the repression of FLC in the absence of sequence specificity.

Several studies identified proteins that directly interact with LHP1. Up to date, EARLY IN SHORT DAYS7 (ESD7), INCURVATA2 (ICU2), SCARECROW (SCR) and SHORT VEGETATIVE PHASE (SVP), CYCLOPHILIN71 (AtCYP71), MULTICOPY SUPRESSOR OF IRA 1 (MSI1) and LHP1interacting Factor 2 (LIF2) were shown to interact with LHP1 (Barrero et al., 2007; Cui and Benfey, 2009; del Olmo et al., 2010; Derkacheva et al., 2013; Latrasse et al., 2011; Li and Luan, 2011). Functional implication of these LHP1 interacting proteins remains obscure in regard to their roles in PRC1mediated gene repression. However, diverse LHP1 interacting proteins indicates that LHP1 plays various roles in plant developmental programs through the interaction with a variety of regulatory proteins. Therefore, identification and characterization of PRC1 components would allow us to understand molecular details on PRC1 in plants. 


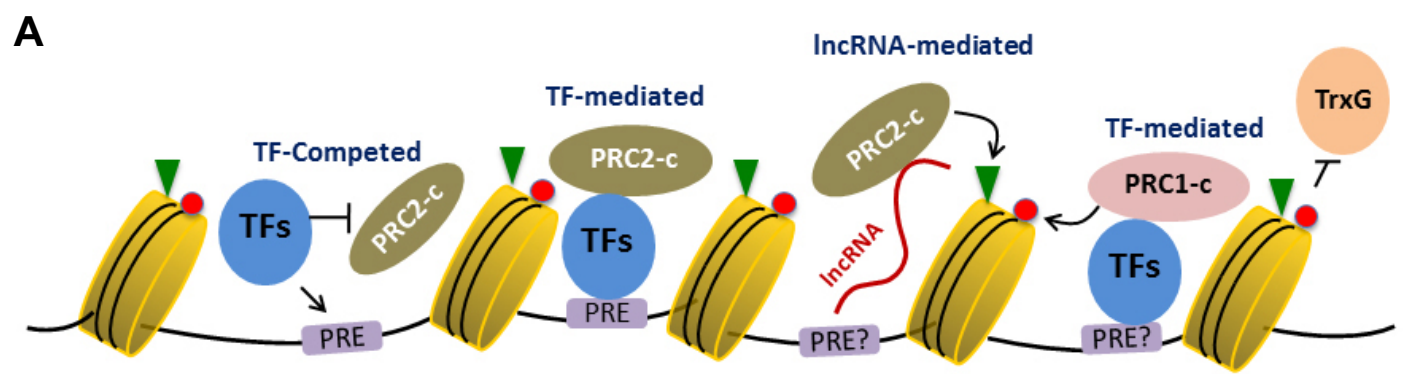

B

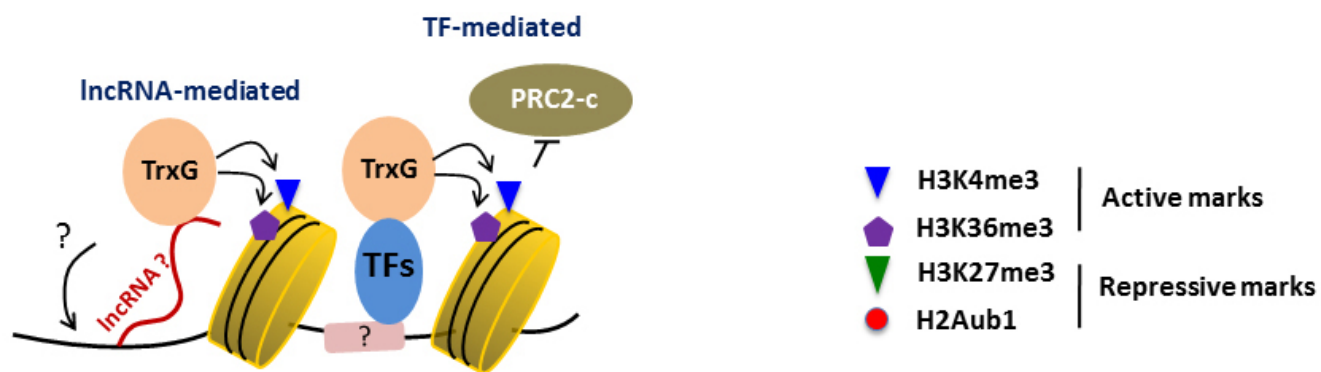

Fig. 2. Several proposed modes of the recruitment of PcG and TrxG complexes. (A) PcG complexes, PRC1 or PRC2 physically interacts with transcription factors (TFs) or IncRNAs to be recruited to specific target loci, containing PRE. Recruited PRC1 and PRC2 catalyze H2Aub1 (red circle) and H3K27me3 (green triangle) on target loci, respectively. Some TFs (i.e. AG) competes PRC2 out of target loci in a time-dependent manner. (B) TrxG complex is recruited to target loci through the interaction with TFs or IncRNAs. Recruited TrxG complex catalyze H3K4me3 (blue triangle) or H3K36me3 (purple pentagon) which inhibit PRC2 activity. TrxG-recruiting IncRNAs or DNA elements have not been identified in Arabidopsis.

TrxG complex antagonize PRC2

Trithorax group (TrxG) proteins activate gene expression through depositing active histone marks, H3K4me3 and H3K36me3 at target chromatin, which often overlap with PcG target chromatin, thus antagonize PcG function (Papp and Muller, 2006; Schwartz and Pirrotta, 2008). As in the case of PRC2, TrxG proteins are also well conserved in eukaryotes (Ringrose and Paro, 2004; Schuettengruber et al., 2007). In yeast, H3K4me3 is catalyzed by TrxG-containing complex called as complex proteins associated with Set1 (COMPASS) (Mohan et al., 2011). COMPASS-like complex is also conserved in other higher eukaryotes, such as mixed lineage leukemia (MLL)complex in mammals.

H3K27me3 and its antagonistic H3K4me3 histone marks are generally localized around transcription start sites (TSSs) at target loci, likely competing with each other. In Drosophila, the presence of $\mathrm{H} 3 \mathrm{~K} 4 \mathrm{me} 3$ and $\mathrm{H} 3 \mathrm{~K} 36 \mathrm{me} 3$ inhibits the catalytic activity of PRC2 (Schmitges et al., 2011; Yuan et al., 2011). Similarly, histone acetylation at H3K27 (H3K27ac) directly inhibit methylation of $\mathrm{H} 3 \mathrm{~K} 27$ by PRC2, as both modifications cannot occur at the same residue (Pasini et al., 2010; Tie et al., 2009; 2014). Another layer of regulation of the antagonistic effect between PcG and TrxG proteins is mediated by H3K27 demethylases, such as Ultrathorax (UTX), which directly associate with COMPASS complex and enhance gene activation by the removal of $\mathrm{H} 3 \mathrm{~K} 27 \mathrm{me} 3$ from target chromatin (Lee et al., 2007a; 2007b).

Similar antagonistic phenomena between PcG and TrxG proteins have been also reported in Arabidopsis. The first identified TrxG protein in Arabidopsis is ARABIDOPSIS HOMOLOG OF TRITHORAX1 (ATX1), a SET-domain protein. Mutations in $A T X 1$ resulted in a number of pleiotropic phenotypes, including early flowering due to the severe reduction of $\mathrm{H} 3 \mathrm{~K} 4 \mathrm{me} 3$ at $F L C$ (Pien et al., 2008; Saleh et al., 2008). Subsequently, ATX1-like genes such as ARABIDOPSIS TRITHORAX-RELATED 3 (ATXR3)/SET DOMAIN GROUP 2 (SDG2) and ARABIDOPSIS TRITHORAX-RELATED 7 (ATXR7)/SET DOMAIN GROUP 25 (SDG25) are also found to act as H3K4me3 methyltransferases in Arabidopsis (Tamada et al., 2009; Yun et al., 2012). Another SET-domain gene, EARLY FLOWERING IN SHORT DAYS (EFS), a homolog of Drosophila absent small homeotic disks1 (ASH1) (Tripoulas et al., 1994), is also identified from mutant screening for early flowering in Arabidopsis (Soppe et al., 1999). $\mathrm{H} 3 \mathrm{~K} 4 \mathrm{me} 3$ and H3K36me3 levels are decreased in efs mutants, indicating EFS acts as a transcriptional activator through catalyzing H3K4 and H3K36 methylation (Kim et al., 2005; Ko et al., 2010; Zhao et al., 2005). Antagonistic relationship between H3K36me3 and H3K27me3 is recently demonstrated in the cold-induced epigenetic control of FLC (Yang et al., 2014a), suggesting that antagonistic effect between TrxG and PcG proteins is also one of well-conserved phenomena in eukaryotes.

However, it should be noted that genome-wide analyses indicate the enrichment of $\mathrm{H} 3 \mathrm{~K} 4 \mathrm{me} 3$ by TrxG and that of H3K27me3 by PRC2 are not always mutually exclusive. Rather, both histone marks do co-reside in a number of developmentally regulated genes in both animals and plants (Bernstein et al., 2006a; Jiang et al., 2008; Roudier et al., 2011; Zhang et al., $2007 ; 2009)$. These bivalent histone marks of H3K4me3 and $\mathrm{H} 3 \mathrm{~K} 27 \mathrm{me} 3$ suggest that the regulation of numerous PcG/TrxG target genes can be achieved by delicate balances between H3K4me3 and H3K27me3 marks (Schwartz et al., 2010).

Like PcG complexes, TrxG proteins act in tissue- and timedependent manners. A TrxG-interacting protein, WDR5, binds to a long non-coding RNAs (IncRNAs), HOXA TRANSCRIPT AT 
THE DISTAL TIP (HOTTIP) and NETTOIE SALMONELLA PAS THEILER'S (NeST), which in turn coordinate the activation of several TrxG target genes through H3K4 methylation (Gomez et al., 2013; Wang and Chang, 2011; Yang et al., 2014b). Up to date, no similar ncRNA has been identified in plants. Instead, a plant specific SAND domain protein, ULTRAPETALA1 (ULT1), has been reported to bind to ATX1 and may be responsible for guiding the ATX1-containing complex to target loci (Carles and Fletcher, 2009). It is still poorly understood how various TrxG complexes can be recruited onto their specific target loci.

\section{RECRUITMENT OF PcG COMPLEX TO TARGET LOCI}

In Arabidopsis, many developmental genes are dynamically marked by $\mathrm{H} 3 \mathrm{~K} 27 \mathrm{me} 3$ in tissue- and time-specific manners (Berr et al., 2009; Deng et al., 2013; Lafos et al., 2011; Oh et al., 2008; Roudier et al., 2011; Zhang et al., 2007). Given that no core subunit of PRC2 has apparent sequence-specific DNA binding ability, initial recruitment, maintenance, and removal of PRC2 may not be simple.

Several mechanisms to direct PRC2 to its target loci have been suggested (Fig. 2). In Drosophila, PRC2 physically interacts with DNA-binding proteins that specifically recognize Polycomb Response Elements (PREs) (Ringrose and Paro, 2004; Schwartz and Pirrotta, 2008). In mammals, consensus DNA motifs in PRE are not obvious, but PRC2 tends to bind to CpG-rich domain region (Ku et al., 2008; Sing et al., 2009; Woo et al., 2010). Alternatively, a plethora of IncRNAs has been identified to associate with PRC2 and suggested as potential PRC2 recruiters, capable of directing PRC2 to target chromatin in cis or in trans.

Currently, two different types of PRC2 recruitment mechanisms have been proposed in Arabidopsis. One is transcription factors (TFs)-mediated and the other is IncRNA-mediated (Fig. 2). Conceptually, TFs generally recognize and bind to certain DNA sequence. Several DNA binding proteins have been shown to bind to PREs and the bindings are required for the PRC2mediated repression (He et al., 2013; Schwartz and Pirrotta, 2008). PREs harbor DNA sequence specifically recognized by certain TFs that in turn aid the recruitment of PRC2 by direct interaction in time- or tissue- specific manners. Several cases of TFs-mediated PRC2 targeting mechanisms are described below. A MYB-domain transcription factor, ASYMMETRIC LEAVES1 (AS1), controls the proximo-distal patterning in leaves (Byrne et al., 2000; Chua et al., 2005). AS1 physically interacts with a LOB-domain transcription factor, AS2, to form a protein complex which acts to silence SAM-specific homeobox domain genes, such as BREIPEDICELLUS (BP) and KNOTTED-LIKE FROM ARABIDOPSIS THALIANA2 (KNAT2) in leaf tissue (Guo et al., 2008; Iwakawa et al., 2002; Lin et al., 2003; Semiarti et al., 2001). AS1-AS2 complex binds directly to DNA element upstream of BP and KNAT2 (Guo et al., 2008). In a recent study, AS1-AS2 complex turned out to interact with PRC2 and recruits PRC2 to cis-DNA element in the promoter regions of $B P$ and KNAT2 (Lodha et al., 2013). Mutations in AS1 or AS2 caused a significant reduction in $\mathrm{H} 3 \mathrm{~K} 27 \mathrm{me} 3$ levels at $B P$ and KNAT2. Furthermore, mutations in AS1/AS2-binding DNA elements also resulted in decrease of $\mathrm{H} 3 \mathrm{~K} 27 \mathrm{me} 3$ accumulation and the derepression of two KNOX genes. Therefore, AS1/AS2-binding DNA elements serve PRE-like function in PRC2-mediated $K N O X$ gene silencing in leaf tissue.

Another candidate PRE was reported from the promoter of LEAFY COTYLEDON2 (LEC2) which is involved in the embryonic development in Arabidopsis (Berger et al., 2011). LEC2 is temporally activated during embryo development and silenced upon the completion of seed development (Stone et al., 2001). A PRE-like element, named repressive LEC2 element (RLE) was identified within the promoter of LEC2. Mutations in RLE abolished the recruitment of PRC2 to $L E C 2$ loci and translocation of intact RLE to the promoter region of an unrelated gene, FLAVONONE 3-HYDROXYLASE $(F 3 H)$, is sufficient to trigger $\mathrm{H} 3 \mathrm{~K} 27 \mathrm{me} 3$ enrichment and repression of $\mathrm{F} 3 \mathrm{H}$. However, it is still not clear how RLE DNA sequence contributes to the recruitment of PRC2 to $L E C 2$ loci. Identification of RLE-binding protein(s) would give us further understanding on the RLEmediated PRC2 recruitment.

A MADS-box transcription factor, AGAMOUS $(A G)$, is required to establish the floral organ identity and the termination of floral meristem in Arabidopsis (Bowman et al., 1989; Lohmann et al., 2001). AG recognizes and binds to the CArG motif located upstream of WUSCHEL (WUS) and then brings up PRC2 complex to allow H3K27me3 to accumulate at WUS chromatin (Liu et al., 2011). Mutations in two CArG sequences at WUS locus caused the reduction in the level of $\mathrm{H} 3 \mathrm{~K} 27 \mathrm{me} 3$ accumulation as well as those of PRC2 and LHP1 enrichment, and thus resulting in the derepression of WUS. It suggests that these CArG sequences serve as a PRE required for the recruitment of PRC2 (Fig. 2). However, it has not been demonstrated that whether AG interacts directly or indirectly with PRC2 to recruit PRC2.

Although AG clearly acts together with PRC2 to silence target genes as described above, another study showed that AG competes with PRC2 to induce its target genes in meristematic cells of Arabidopsis (Sun et al., 2014) (Fig. 2). KNUCKLES (KNU) is activated by $A G$ at floral stage 6 and is essential for the initiation of cell differentiation in floral meristem. Interestingly, there is a discrepancy between the induction time point of $A G$ and its downstream gene KNU (Sun et al., 2009). AG is turned on by WUS during an early time point of floral stage (stage 3 ). The induction of $K N U$, however, takes place around floral stage 6 in meristem tissue, taking at least two more days. This discrepancy was explained by the finding of competition between $A G$ and PRC2 for a specific PRE DNA element located within the promoter region of $K N U$. Induced $A G$ at stage 3 needs time to compete with and evict PRC2 from the PRE element at the KNU promoter. Then at stage 6 , the removal of PRC2 allows strong activation of $K N U$ to initiate cell differentiation at apical meristem. These data indicate that the PRE/PRC2-mediated silencing is dynamically controlled in time- and tissue-specific manners.

A genome-wide ChIP-Seq using FIE-HA transgenic Arabidopsis plants identified several common binding motifs, including the GA-repeat motif frequently found in Drosophila PREs (Deng et al., 2013). Notably, KNU also contains a GA-repeat like motif within its PRE sequence. It remains to be tested whether this motif actually functions to recruit PRC2 to target loci. In addition, it is worth noting that several different DNA motifs are found at distinct subsets of FIE-HA binding sites in Arabidopsis, suggesting that PRC2 recruitment in plants can be achieved by many different factors.

VP1/ABI3-LIKE1 (VAL1) and VAL2 encode B3 DNA binding domain proteins and they are essential components in the prevention of embryonic trait in somatic tissues after seed development by the suppression of embryo-specific genes, such as LEC1 and LEC2 (Suzuki et al., 2007). A recent study showed that VAL proteins interact with PRC1 and recruit PRC1 to suppress embryonic trait genes after germination (Yang et al., 2013). This study suggests that VAL proteins act as a PRC1 recruiter, especially in seeds. It is not known how the target specificity of VALs-PRC1 can be achieved and whether PRE-like DNA elements are also involved in this process.

Currently, several long noncoding RNAs (IncRNAs) have been 
emerged as a PRC2-interacting/recruiting component in eukaryotes (Fig. 2). The direct interaction between PRC2 and an IncRNA, RepA/Xist, was first demonstrated in mammalian $X$ chromosome (Zhao et al., 2008). Another IncRNA, HOX ANTISENSE INTERGENIC RNA (HOTAIR), was shown to recruit PRC2 to the HOXD locus (Rinn and Chang, 2012; Rinn et al., 2007). Genome-wide RNA immunoprecipitation followed by sequencing approaches revealed that PRC2 associates with a large number of IncRNA transcripts, indicating the capability of PRC2 binding with over 9,000 transcripts (Kanhere et al., 2010; Khalil et al., 2009; Mercer and Mattick, 2013; Zhao et al., 2010). Despite that thousands of IncRNAs have been identified or predicted in silico in Arabidopsis (Liu et al., 2012; Wang et al., 2014a), only a handful of IncRNAs has been functionally characterized. For example, two IncRNAs, COLD INDUCED LONG ANTISENSE INTEAGENIC RNA (COOLAIR) and COLD ASSISTED INTRONIC NONCODING RNA (COLDAIR), are involved in the regulation of FLC (Heo and Sung, 2011; Swiezewski et al., 2009).

COOLAIR is a collection of antisense transcripts that have alternative transcripts at $3^{\prime}$ end, producing proximal forms or distal forms (Liu et al., 2010). The splicing of COOLAIR is functionally important and correlates with different states of sense FLC transcription (Marquardt et al., 2014; Wang et al., 2014c). These alternative splicing events are controlled by several autonomous pathway proteins, including FCA, FPA, and FY. FCA and FPA are homologs of the 3' processing factors Cstf64, and Cstf77, respectively and $F Y$ is a homolog of splicing factor PRP8. Active usaqe of the proximal polv $(A)$ site results in quantitative downrequlation of $F L C$, which requires an $\mathrm{H} 3 \mathrm{~K} 4 \mathrm{me} 2$ demethvlase, $\mathrm{FLD}$, to catalyze $\mathrm{H} 3 \mathrm{~K} 4 \mathrm{me} 2$, a repressive mark at $F L C$ chromatin (Liu et al., 2010). However, how FLD is activated and utilized by the use of proximal poly $(A)$ site of COOLAIR remains unknown. COLDAIR is a sense InCRNA originated from the intron region of $F L C$ and involved in the vernalization-mediated $F L C$ repression (Heo and Sung, 2011). COLDAIR is induced by cold and reaches peak at around after 20 days of cold. COLDAIR RNAi knockdown lines exhibited late flowering phenotypes due to the defect in the recruitment of CLF, a component of PRC2, to FLC chromatin in response to vernalization, suggesting that COLDAIR is required for the recruitment of $\mathrm{PRC} 2$ onto FLC upon vernalization.

Another IncRNA, HIDDEN TREASURE1 (HID1), is increased uniquely by red-light irradiation and shown to be involved in the repression of PHYTOCHROME-INTERACTING FACTOR3 (PIF3) (Wang et al., 2014b). RNA motifs with stem-loop structures of HID appear to be important modules for the function of HID1. In contrast to either COOLAIR or COLDAIR, HID1 likely acts as a trans-acting IncRNA. It is expected that more noncoding RNAs will be identified as important regulatory components, including PcG/TrxG-mediated gene regulation.

\section{PcG-MEDIATED CHROMATIN LOOPING}

Chromosomes, physical storage units of DNA, adopt highly organized structure and occupy distinct territories with preferential locations in the nucleus (Lanctot et al., 2007). Though several PRE DNA motif and IncRNAs are suggested as recruiting factors for PcG-containing complexes, our understanding on PREs- and IncRNAs-mediated PcG recruitment is still limited. Genome-wide studies in Drosophila showed that PcG proteins and discrete PRE DNA-elements cluster into large genomic domains, referred to as "Polycomb bodies $(\mathrm{Pb})$ ", which are colocalized with H3K27me3 marks (Buchenau et al., 1998, Messmer et al., 1992; Pirrotta, 1997).
The development of chromosome conformation capture (3C) assay tool allows to measure physical and spatial interactions among discrete chromatin regions (Dekker et al., 2002). For example, PREs in the homeotic bithorax complex (BX-C) in Drosophila exist in contact with other PREs of repressed HOX genes by the formation of multiple chromatin loops (Lanzuolo et al., 2007). Immuno-fluorescent in situ hybridization (ImmunoFISH) assay showed that PcG-mediated gene silencing take places in Pb loci (Bantignies and Cavalli, 2011; Grimaud et al., 2006). Therefore, it is conceivable that PcG proteins and PREs act to create higher-order structures in nucleus, and these PcGcondensed $\mathrm{Pb}$ loci are critical to ensure proper gene silencing through the enrichment of $\mathrm{H} 3 \mathrm{~K} 27 \mathrm{me} 3$ repressive marks at target chromatin (Cheutin and Cavalli, 2014; Schuettengruber et al., 2009; Schwartz et al., 2006: Sexton et al., 2012).

Higher-order chromatin structures are also observed at FLC, a common target of TrxG and PcG in Arabidopsis (Crevillen et al., 2013). Using 3C, a qene loop between the $5^{\prime}$ and $3^{\prime}$ flankina reqions of the FLC locus appears to be correlated with the state of FLC transcription before vernalization. This loop is disrupted durina vernalization. and the disruption of the loop coincides with the cold-induced FLC transcriptional shut-down. Mutations in $B A F 60$, which encodes a SWI/SNF ATP-dependent chromatin remodeler. exhibit a stronqer formation of this aene loop was detected and thus resulted in the up-regulation of FLC (Jegu et al., 2014).

The formation of hiqher-order of chromatin structure is apparent in the studv of " $F L C$ " bodv. Nuclear re-localization events at the FLC locus were observed when FLC is repressed bv vernalization (Rosa et al., 2013). VRN5 encodes a PHD finger protein and is required for the PRC2-mediated silencing of FLC by vernalization. In vrn5 mutants, this nuclear re-localization by vernalization is abolished, indicating that the nuclear re-location is one of processes that occur during the vernalization-mediated stable silencing of FLC. Taken together, higher-order chromatin structural change is likely closely related to transcriptional states of PcG and TrxG target genes in Arabidopsis.

\section{CONCLUSION}

PRC2 and PRC1 play critical roles in the maintenance of stable transcriptional states of developmental genes through histone modifications, H3K27me3 and H2Aub1, respectively. PcGmediated repressive marks are antagonized by TrxG complex, which catalyzes $\mathrm{H} 3 \mathrm{~K} 4 \mathrm{me} 3$ and $\mathrm{H} 3 \mathrm{~K} 36 \mathrm{me} 3$ histone marks. To ensure proper development, PcG- and TrxG-mediated regulation of gene expression need to be precisely programmed in time- and tissue-dependent manners. One of enigmas in the study of PcG- and TrxG-mediated regulation of gene expression is how these complexes are recruited to subsets of target genes according to developmental programs and environmental cues. Up to date, PRE cis-elements, transcription factors (TFs), and IncRNAs are proposed to contribute to the recruitment. It is expected that various mechanisms exist, and further identifications of PcG-interacting factors would extend our understanding and allow us to extract fundamental principles underlying epigenetic regulation of eukaryote developmental programs.

\section{ACKNOWLEDGMENTS}

Sung Lab is supported by grants from National Science Foundation, National Institute of Health and USDA.

\section{REFERENCES}

Akasaka, T., Kanno, M., Balling, R., Mieza, M.A., Taniguchi, M., and 
Koseki, H. (1996). A role for mel-18, a Polycomb group-related vertebrate gene, during theanteroposterior specification of the axial skeleton. Development 122, 1513-1522.

Bantignies, F., and Cavalli, G. (2011). Polycomb group proteins: repression in 3D. Trends Genet. 27, 454-464.

Bardos, J.I., Saurin, A.J., Tissot, C., Duprez, E., and Freemont, P.S (2000). HPC3 is a new human polycomb orthologue that interacts and associates with RING1 and Bmi1 and has transcriptional repression properties. J. Biol. Chem. 275, 28785-28792.

Barrero, J.M., Gonzalez-Bayon, R., del Pozo, J.C., Ponce, M.R., and Micol, J.L. (2007). INCURVATA2 encodes the catalytic subunit of DNA Polymerase alpha and interacts with genes involved in chromatin-mediated cellular memory in Arabidopsis thaliana. Plant Cell 19, 2822-2838.

Bastow, R., Mylne, J.S., Lister, C., Lippman, Z., Martienssen, R.A., and Dean, C. (2004). Vernalization requires epigenetic silencing of FLC by histone methylation. Nature 427, 164-167.

Beh, L.Y., Colwell, L.J., and Francis, N.J. (2012). A core subunit of Polycomb repressive complex 1 is broadly conserved in function but not primary sequence. Proc. Natl. Acad. Sci. USA 109, E1063-1071.

Ben-Saadon, R., Zaaroor, D., Ziv, T., and Ciechanover, A. (2006). The polycomb protein Ring1B generates self atypical mixed ubiquitin chains required for its in vitro histone $\mathrm{H} 2 \mathrm{~A}$ ligase activity. Mol. Cell 24, 701-711.

Berger, N., Dubreucq, B., Roudier, F., Dubos, C., and Lepiniec, L. (2011). Transcriptional regulation of Arabidopsis LEAFY COTYLEDON2 involves RLE, a cis-element that regulates trimethylation of histone $\mathrm{H} 3$ at lysine-27. Plant Cell 23, 4065-4078.

Bernstein, B.E., Mikkelsen, T.S., Xie, X., Kamal, M., Huebert, D.J., Cuff, J., Fry, B., Meissner, A., Wernig, M., Plath, K., et al. (2006a). A bivalent chromatin structure marks key developmental genes in embryonic stem cells. Cell 125, 315-326.

Bernstein, E., Duncan, E.M., Masui, O., Gil, J., Heard, E., and Allis, C.D. (2006b). Mouse polycomb proteins bind differentially to methylated histone $\mathrm{H} 3$ and RNA and are enriched in facultative heterochromatin. Mol. Cell. Biol. 26, 2560-2569.

Berr, A., Xu, L., Gao, J., Cognat, V., Steinmetz, A., Dong, A., and Shen, W.H. (2009). SET DOMAIN GROUP25 encodes a histone methyltransferase and is involved in FLOWERING LOCUS C activation and repression of flowering. Plant Physiol. 151, 14761485.

Bouyer, D., Roudier, F., Heese, M., Andersen, E.D., Gey, D. Nowack, M.K., Goodrich, J., Renou, J.P., Grini, P.E., Colot, V., et al. (2011). Polycomb repressive complex 2 controls the embryoto-seedling phase transition. PLoS Genet. 7, e1002014.

Bowman, J.L., Smyth, D.R., and Meyerowitz, E.M. (1989). Genes directing flower development in Arabidopsis. Plant Cell 1, 37-52.

Bratzel, F., Lopez-Torrejon, G., Koch, M., Del Pozo, J.C., and Calonje, M. (2010). Keeping cell identity in arabidopsis requires PRC1 RING-finger homologs that catalyze H2A monoubiquitination. Curr. Biol. 20, 1853-1859.

Buchenau, P., Hodgson, J., Strutt, H., and Arndt-Jovin, D.J. (1998). The distribution of polycomb-group proteins during cell division and development in Drosophila embryos: impact on models for silencing. J. Cell Biol. 141, 469-481.

Buchwald, G., van der Stoop, P., Weichenrieder, O., Perrakis, A. van Lohuizen, M., and Sixma, T.K. (2006). Structure and E3ligase activity of the Ring-Ring complex of polycomb proteins Bmi1 and Ring1b. EMBO J. 25, 2465-2474.

Byrne, M.E., Barley, R., Curtis, M., Arroyo, J.M., Dunham, M., Hudson, A., and Martienssen, R.A. (2000). Asymmetric leaves1 mediates leaf patterning and stem cell function in Arabidopsis Nature 408, 967-971.

Calonje, M., Sanchez, R., Chen, L., and Sung, Z.R. (2008). EMBRYONIC FLOWER1 participates in polycomb groupmediated AG gene silencing in Arabidopsis. Plant Cell 20, 277 291.

Cao, R., Wang, L., Wang, H., Xia, L., Erdjument-Bromage, H., Tempst, P., Jones, R.S., and Zhang, Y. (2002). Role of histone H3 lysine 27 methylation in Polycomb-group silencing. Science 298, 1039-1043.

Cao, R., Tsukada, Y., and Zhang, Y. (2005). Role of Bmi-1 and Ring1 A in H2A ubiquitylation and Hox gene silencing. Mol. Cell 20, 845-854.

Carles, C.C., and Fletcher, J.C. (2009). The SAND domain protein
ULTRAPETALA1 acts as a trithorax group factor to regulate cell fate in plants. Genes Dev. 23, 2723-2728.

Chanvivattana, Y., Bishopp, A., Schubert, D., Stock, C., Moon, Y.H., Sung, Z.R., and Goodrich, J. (2004). Interaction of Polycombgroup proteins controlling flowering in Arabidopsis. Development 131, 5263-5276.

Cheutin, T., and Cavalli, G. (2014). Polycomb silencing: from linear chromatin domains to 3D chromosome folding. Curr. Opin. Genet. Dev. 25, 30-37.

Chua, Y.L., Channeliere, S., Mott, E., and Gray, J.C. (2005). The bromodomain protein GTE6 controls leaf development in Arabidopsis by histone acetylation at ASYMMETRIC LEAVES1. Genes Dev. 19, 2245-2254

Crevillen, P., Sonmez, C., Wu, Z., and Dean, C. (2013). A gene loop containing the floral repressor FLC is disrupted in the early phase of vernalization. EMBO J. 32, 140-148.

Cui, H., and Benfey, P.N. (2009). Interplay between SCARECROW, GA and LIKE HETEROCHROMATIN PROTEIN 1 in ground tissue patterning in the Arabidopsis root. Plant J. 58, 1016-1027.

Czermin, B., Melfi, R., McCabe, D., Seitz, V., Imhof, A., and Pirrotta, V. (2002). Drosophila enhancer of Zeste/ESC complexes have a histone $\mathrm{H} 3$ methyltransferase activity that marks chromosomal Polycomb sites. Cell 111, 185-196.

De Lucia, F., Crevillen, P., Jones, A.M., Greb, T., and Dean, C. (2008). A PHD-polycomb repressive complex 2 triggers the epigenetic silencing of FLC during vernalization. Proc. Natl. Acad. Sci. USA 105, 16831-16836.

Dekker, J., Rippe, K., Dekker, M., and Kleckner, N. (2002). Capturing chromosome conformation. Science 295, 1306-1311.

del Olmo, I., Lopez-Gonzalez, L., Martin-Trillo, M.M., MartinezZapater, J.M., Pineiro, M., and Jarillo, J.A. (2010). EARLY IN SHORT DAYS 7 (ESD7) encodes the catalytic subunit of DNA polymerase epsilon and is required for flowering repression through a mechanism involving epigenetic gene silencing. Plant $\mathrm{J}$. 61, 623-636.

Deng, W., Buzas, D.M., Ying, H., Robertson, M., Taylor, J., Peacock, W.J., Dennis, E.S., and Helliwell, C. (2013). Arabidopsis polycomb repressive complex 2 binding sites contain putative GAGA factor binding motifs within coding regions of genes. BMC Genomics 14, 593.

Derkacheva, M., Steinbach, Y., Wildhaber, T., Mozgova, I., Mahrez, W., Nanni, P., Bischof, S., Gruissem, W., and Hennig, L. (2013). Arabidopsis MSI1 connects LHP1 to PRC2 complexes. EMBO J. 32, 2073-2085.

Eskeland, R., Leeb, M., Grimes, G.R., Kress, C., Boyle, S., Sproul, D., Gilbert, N., Fan, Y., Skoultchi, A.l., Wutz, A., et al. (2010). Ring1B compacts chromatin structure and represses gene expression independent of histone ubiquitination. Mol. Cell 38, $452-464$.

Exner, V., Aichinger, E., Shu, H., Wildhaber, T., Alfarano, P., Caflisch, A., Gruissem, W., Kohler, C., and Hennig, L. (2009). The chromodomain of LIKE HETEROCHROMATIN PROTEIN 1 is essential for $\mathrm{H} 3 \mathrm{~K} 27 \mathrm{me} 3$ binding and function during Arabidopsis development. PLoS One 4, e5335.

Gomez, J.A., Wapinski, O.L., Yang, Y.W., Bureau, J.F., Gopinath, S., Monack, D.M., Chang, H.Y., Brahic, M., and Kirkegaard, K. (2013). The NeST long ncRNA controls microbial susceptibility and epigenetic activation of the interferon-gamma locus. Cell 152, 743-754.

Goodrich, J., Puangsomlee, P., Martin, M., Long, D., Meyerowitz, E.M., and Coupland, G. (1997). A Polycomb-group gene regulates homeotic gene expression in Arabidopsis. Nature 386, 44-51.

Grimaud, C., Bantignies, F., Pal-Bhadra, M., Ghana, P., Bhadra, U., and Cavalli, G. (2006). RNAi components are required for nuclear clustering of Polycomb group response elements. Cell 124, 957971.

Guo, M., Thomas, J., Collins, G., and Timmermans, M.C. (2008) Direct repression of KNOX loci by the ASYMMETRIC LEAVES1 complex of Arabidopsis. Plant Cell 20, 48-58.

He, Y., Yu, Y., Zhang, Y., Song, J., Mitra, A., Zhang, Y., Wang, Y., Sun, D., and Zhang, S. (2012). Genome-wide bovine H3K27me3 modifications and the regulatory effects on genes expressions in peripheral blood lymphocytes. PLoS One 7, e39094.

$\mathrm{He}$, C., Huang, H., and Xu, L. (2013). Mechanisms guiding Polycomb activities during gene silencing in Arabidopsis thaliana. 
Front Plant Sci. 4, 454

Heo, J.B., and Sung, S. (2011). Vernalization-mediated epigenetic silencing by a long intronic noncoding RNA. Science 331, 76-79.

Iwakawa, H., Ueno, Y., Semiarti, E., Onouchi, H., Kojima, S. Tsukaya, H., Hasebe, M., Soma, T., Ikezaki, M., Machida, C., et al. (2002). The ASYMMETRIC LEAVES2 gene of Arabidopsis thaliana, required for formation of a symmetric flat leaf lamina, encodes a member of a novel family of proteins characterized by cysteine repeats and a leucine zipper. Plant Cell Physiol. 43, 467478

Jegu, T., Latrasse, D., Delarue, M., Hirt, H., Domenichini, S., Ariel, F., Crespi, M., Bergounioux, C., Raynaud, C., and Benhamed, M. (2014). The BAF60 subunit of the SWI/SNF chromatinremodeling complex directly controls the formation of a gene loop at FLOWERING LOCUS C in Arabidopsis. Plant Cell 26, 538-551.

Jiang, D., Wang, Y., and He, Y. (2008). Repression of FLOWERING LOCUS $C$ and FLOWERING LOCUS $T$ by the Arabidopsis Polycomb repressive complex 2 components. PLoS One 3, e3404.

Kanhere, A., Viiri, K., Araujo, C.C., Rasaiyaah, J., Bouwman, R.D., Whyte, W.A., Pereira, C.F., Brookes, E., Walker, K., Bell, G.W., et al. (2010). Short RNAs are transcribed from repressed polycomb target genes and interact with polycomb repressive complex-2. Mol. Cell 38, 675-688.

Khalil, A.M., Guttman, M., Huarte, M., Garber, M., Raj, A., Rivea Morales, D., Thomas, K., Presser, A., Bernstein, B.E., van Oudenaarden, A., et al. (2009). Many human large intergenic noncoding RNAs associate with chromatin-modifying complexes and affect gene expression. Proc. Natl. Acad. Sci. USA 106, 11667-11672.

Kim, S.Y., He, Y., Jacob, Y., Noh, Y.S., Michaels, S., and Amasino, R. (2005). Establishment of the vernalization-responsive, winterannual habit in Arabidopsis requires a putative histone $\mathrm{H} 3$ methyl transferase. Plant Cell 17, 3301-3310.

Kim, D.H., Doyle, M.R., Sung, S., and Amasino, R.M. (2009) Vernalization: winter and the timing of flowering in plants. Annu. Rev. Cell Dev. Biol. 25, 277-299.

Kim, S.Y., Lee, J., Eshed-Williams, L., Zilberman, D., and Sung, Z.R. (2012). EMF1 and PRC2 cooperate to repress key regulators of Arabidopsis development. PLoS Genet. 8, e1002512.

Ko, J.H., Mitina, I., Tamada, Y., Hyun, Y., Choi, Y., Amasino, R.M., Noh, B., and Noh, Y.S. (2010). Growth habit determination by the balance of histone methylation activities in Arabidopsis. EMBO J. $29,3208-3215$

Kohler, C., Hennig, L., Spillane, C., Pien, S., Gruissem, W., and Grossniklaus, U. (2003). The Polycomb-group protein MEDEA regulates seed development by controlling expression of the MADS-box gene PHERES1. Genes Dev. 17, 1540-1553.

Ku, M. Koche, R.P., Rheinbay, E., Mendenhall, E.M., Endoh, M. Mikkelsen, T.S., Presser, A., Nusbaum, C., Xie, X., Chi, A.S., et al. (2008). Genomewide analysis of PRC1 and PRC2 occupancy identifies two classes of bivalent domains. PLoS Genet. 4. e1000242.

Lafos, M., Kroll, P., Hohenstatt, M.L., Thorpe, F.L., Clarenz, O., and Schubert, D. (2011). Dynamic regulation of H3K27 trimethylation during Arabidopsis differentiation. PLoS Genet. 7, e1002040.

Lanctot, C. Kaspar, C., and Cremer, T. (2007). Positioning of the mouse Hox gene clusters in the nuclei of developing embryos and differentiating embryoid bodies. Exp. Cell Res. 313, 14491459.

Lanzuolo, C., Roure, V., Dekker, J., Bantignies, F., and Orlando, V. (2007). Polycomb response elements mediate the formation of chromosome higher-order structures in the bithorax complex. Nat. Cell Biol. 9, 1167-1174.

Latrasse, D., Germann, S., Houba-Herin, N., Dubois, E., BuiProdhomme, D., Hourcade, D., Juul-Jensen, T., Le Roux, C. Majira, A., Simoncello, N., et al. (2011). Control of flowering and cell fate by LIF2, an RNA binding partner of the polycomb complex component LHP1. PLoS One 6, e16592.

Lee, J.S., Shukla, A., Schneider, J., Swanson, S.K., Washburn, M.P., Florens, L., Bhaumik, S.R., and Shilatifard, A. (2007a). Histone crosstalk between $\mathrm{H} 2 \mathrm{~B}$ monoubiquitination and $\mathrm{H} 3$ methylation mediated by COMPASS. Cell 131, 1084-1096.

Lee, M.G., Villa, R., Trojer, P., Norman, J., Yan, K.P., Reinberg, D. Di Croce, L., and Shiekhattar, R. (2007b). Demethylation of H3K27 regulates polycomb recruitment and H2A ubiquitination.
Science 318, 447-450.

Levy, Y.Y., Mesnage, S., Mylne, J.S., Gendall, A.R., and Dean, C. (2002). Multiple roles of Arabidopsis VRN1 in vernalization and flowering time control. Science 297, 243-246.

Lewis, E.B. (1978). A gene complex controlling segmentation in Drosophila. Nature 276, 565-570.

$\mathrm{Li}, \mathrm{H}$., and Luan, S. (2011). The cyclophilin AtCYP71 interacts with CAF-1 and LHP1 and functions in multiple chromatin remodeling processes. Mol. Plant 4, 748-758.

Li, W., Wang, Z., Li, J., Yang, H., Cui, S., Wang, X., and Ma, L. (2011). Overexpression of AtBMI1C, a polycomb group protein gene, accelerates flowering in Arabidopsis. PLoS One 6, e21364.

Lin, W.C., Shuai, B., and Springer, P.S. (2003). The Arabidopsis LATERAL ORGAN BOUNDARIES-domain gene ASYMMETRIC LEAVES2 functions in the repression of KNOX gene expression and in adaxial-abaxial patterning. Plant Cell 15, 2241-2252.

Liu, F., Marquardt, S., Lister, C., Swiezewski, S., and Dean, C. (2010). Targeted $3^{\prime}$ processing of antisense transcripts triggers Arabidopsis FLC chromatin silencing. Science 327, 94-97.

Liu, X., Kim, Y.J., Muller, R., Yumul, R.E., Liu, C., Pan, Y., Cao, X., Goodrich, J., and Chen, X. (2011). AGAMOUS terminates floral stem cell maintenance in Arabidopsis by directly repressing WUSCHEL through recruitment of Polycomb Group proteins. Plant Cell 23, 3654-3670.

Liu, J., Jung, C., Xu, J., Wang, H., Deng, S., Bernad, L., ArenasHuertero, C., and Chua, N.H. (2012). Genome-wide analysis uncovers regulation of long intergenic noncoding RNAs in Arabidopsis. Plant Cell 24, 4333-4345.

Lodha, M., Marco, C.F., and Timmermans, M.C. (2013). The ASYMMETRIC LEAVES complex maintains repression of KNOX homeobox genes via direct recruitment of Polycomb-repressive complex2. Genes Dev. 27, 596-601.

Lohmann, J.U., Hong, R.L., Hobe, M., Busch, M.A., Parcy, F., Simon R., and Weigel, D. (2001). A molecular link between stem cell regulation and floral patterning in Arabidopsis. Cell 105, 793-803.

Makarevich, G., Leroy, O., Akinci, U., Schubert, D., Clarenz, O., Goodrich, J., Grossniklaus, U., and Kohler, C. (2006). Different Polycomb group complexes regulate common target genes in Arabidopsis. EMBO Rep. 7, 947-952.

Margueron, R., and Reinberg, D. (2011). The Polycomb complex PRC2 and its mark in life. Nature 469, 343-349.

Margueron, R., Justin, N., Ohno, K., Sharpe, M.L., Son, J., Drury, W.J., 3rd, Voigt, P., Martin, S.R., Taylor, W.R., De Marco, V., et al (2009). Role of the polycomb protein EED in the propagation of repressive histone marks. Nature 461, 762-767.

Marquardt, S., Raitskin, O., Wu, Z., Liu, F., Sun, Q., and Dean, C. (2014). Functional consequences of splicing of the antisense transcript COOLAIR on FLC transcription. Mol. Cell 54, 156-165.

Mercer, T.R., and Mattick, J.S. (2013). Understanding the regulatory and transcriptional complexity of the genome through structure. Genome Res. 23, 1081-1088

Messmer, S., Franke, A., and Paro, R. (1992). Analysis of the functional role of the Polycomb chromo domain in Drosophila melanogaster. Genes Dev. 6, 1241-1254.

Min, J., Zhang, Y., and Xu, R.M. (2003). Structural basis for specific binding of Polycomb chromodomain to histone $\mathrm{H} 3$ methylated at Lys 27. Genes Dev. 17, 1823-1828.

Mohan, M., Herz, H.M., Smith, E.R., Zhang, Y., Jackson, J., Washburn, M.P., Florens, L., Eissenberg, J.C., and Shilatifard, A (2011). The COMPASS family of H3K4 methylases in Drosophila. Mol. Cell. Biol. 31, 4310-4318.

Molitor, A., and Shen, W.H. (2013). The polycomb complex PRC1: composition and function in plants. J. Genet. Genomics 40, 231 238.

Moon, Y.H., Chen, L., Pan, R.L., Chang, H.S., Zhu, T., Maffeo, D.M., and Sung, Z.R. (2003). EMF genes maintain vegetative development by repressing the flower program in Arabidopsis. Plant Cell 15, 681-693.

Muller, R., and Goodrich, J. (2011). Sweet memories: epigenetic control in flowering. F1000 Biol. Rep. 3, 13.

Muller, J., Hart, C.M., Francis, N.J., Vargas, M.L., Sengupta, A., Wild, B., Miller, E.L., O'Connor, M.B., Kingston, R.E., and Simon, J.A. (2002). Histone methyltransferase activity of a Drosophila Polycomb group repressor complex. Cell 111, 197-208.

Mylne, J.S., Barrett, L., Tessadori, F., Mesnage, S., Johnson, L., Bernatavichute, Y.V., Jacobsen, S.E., Fransz, P., and Dean, C. 
(2006). LHP1, the Arabidopsis homologue of HETEROCHROMATIN PROTEIN1, is required for epigenetic silencing of FLC. Proc. Natl. Acad. Sci. USA 103, 5012-5017.

Oh, S., Park, S., and van Nocker, S. (2008). Genic and global functions for Paf1C in chromatin modification and gene expression in Arabidopsis. PLoS Genet. 4, e1000077.

Papp, B., and Muller, J. (2006). Histone trimethylation and the maintenance of transcriptional ON and OFF states by trxG and PcG proteins. Genes Dev. 20, 2041-2054.

Pasini, D., Malatesta, M., Jung, H.R., Walfridsson, J., Willer, A., Olsson, L., Skotte, J., Wutz, A., Porse, B., Jensen, O.N., et al. (2010). Characterization of an antagonistic switch between histone H3 lysine 27 methylation and acetylation in the transcriptional regulation of Polycomb group target genes. Nucleic Acids Res. 38, 4958-4969.

Pien, S., and Grossniklaus, U. (2007). Polycomb group and trithorax group proteins in Arabidopsis. Biochim. Biophys. Acta 1769, 375382.

Pien, S., Fleury, D., Mylne, J.S., Crevillen, P., Inze, D., Avramova, Z., Dean, C., and Grossniklaus, U. (2008). ARABIDOPSIS TRITHORAX1 dynamically regulates FLOWERING LOCUS C activation via histone 3 lysine 4 trimethylation. Plant Cell 20, 580588.

Pirrotta, V. (1997). Chromatin-silencing mechanisms in Drosophila maintain patterns of gene expression. Trends Genet. 13, 314-318.

Ringrose, L., and Paro, R. (2004). Epigenetic regulation of cellular memory by the Polycomb and Trithorax group proteins. Ann. Rev. Genet. 38, 413-443.

Rinn, J.L., and Chang, H.Y. (2012). Genome regulation by long noncoding RNAs. Ann. Rev. Biochem. 81, 145-166.

Rinn, J.L., Kertesz, M., Wang, J.K., Squazzo, S.L., Xu, X., Brugmann, S.A., Goodnough, L.H., Helms, J.A., Farnham, P.J., Segal, E., et al. (2007). Functional demarcation of active and silent chromatin domains in human HOX loci by noncoding RNAs. Cell 129, 13111323.

Rosa, S., De Lucia, F., Mylne, J.S., Zhu, D., Ohmido, N., Pendle, A., Kato, N., Shaw, P., and Dean, C. (2013). Physical clustering of FLC alleles during Polycomb-mediated epigenetic silencing in vernalization. Genes Dev. 27, 1845-1850.

Roudier, F., Ahmed, I., Berard, C., Sarazin, A., Mary-Huard, T., Cortijo, S., Bouyer, D., Caillieux, E., Duvernois-Berthet, E., AlShikhley, L., et al. (2011). Integrative epigenomic mapping defines four main chromatin states in Arabidopsis. EMBO J. 30, 1928-1938.

Saleh, A., Alvarez-Venegas, R., Yilmaz, M., Le, O., Hou, G., Sadder, M., Al-Abdallat, A., Xia, Y., Lu, G., Ladunga, I., et al. (2008). The highly similar Arabidopsis homologs of trithorax ATX1 and ATX2 encode proteins with divergent biochemical functions. Plant Cell $20,568-579$.

Sanchez-Pulido, L., Devos, D., Sung, Z.R., and Calonje, M. (2008) RAWUL: a new ubiquitin-like domain in PRC1 ring finger proteins that unveils putative plant and worm PRC1 orthologs. BMC Genomics 9, 308.

Schatlowski, N., Creasey, K., Goodrich, J., and Schubert, D. (2008). Keeping plants in shape: polycomb-group genes and histone methylation. Semin. Cell Dev. Biol. 19, 547-553.

Schmitges, F.W., Prusty, A.B., Faty, M., Stutzer, A., Lingaraju, G.M., Aiwazian, J., Sack, R., Hess, D., Li, L., Zhou, S., et al. (2011). Histone methylation by PRC2 is inhibited by active chromatin marks. Mol. Cell 42, 330-341.

Schubert, D., Clarenz, O., and Goodrich, J. (2005). Epigenetic control of plant development by Polycomb-group proteins. Curr. Opin. Plant Biol. 8, 553-561.

Schuettengruber, B., Chourrout, D., Vervoort, M., Leblanc, B., and Cavalli, G. (2007). Genome regulation by polycomb and trithorax proteins. Cell 128, 735-745.

Schuettengruber, B., Ganapathi, M., Leblanc, B., Portoso, M. Jaschek, R., Tolhuis, B., van Lohuizen, M., Tanay, A., and Cavalli, G. (2009). Functional anatomy of polycomb and trithorax chromatin landscapes in Drosophila embryos. PLoS Biol. 7, e13.

Schwartz, Y.B., and Pirrotta, V. (2007). Polycomb silencing mechanisms and the management of genomic programmes. Nat. Rev. Genet. 8, 9-22.

Schwartz, Y.B., and Pirrotta, V. (2008). Polycomb complexes and epigenetic states. Curr. Opin. Plant Biol. 20, 266-273.

Schwartz, Y.B., Kahn, T.G., Nix, D.A., Li, X.Y., Bourgon, R., Biggin,
M., and Pirrotta, V. (2006). Genome-wide analysis of polycomb targets in Drosophila melanogaster. Nat. Genet. 38, 700-705.

Schwartz, Y.B., Kahn, T.G., Stenberg, P., Ohno, K., Bourgon, R. and Pirrotta, V. (2010). Alternative epigenetic chromatin states of polycomb target genes. PLoS Genet. 6, e1000805.

Semiarti, E., Ueno, Y., Tsukaya, H., Iwakawa, H., Machida, C., and Machida, Y. (2001). The ASYMMETRIC LEAVES2 gene of Arabidopsis thaliana regulates formation of a symmetric lamina, establishment of venation and repression of meristem-related homeobox genes in leaves. Development 128, 1771-1783.

Sexton, T., Yaffe, E., Kenigsberg, E., Bantignies, F., Leblanc, B., Hoichman, M., Parrinello, H., Tanay, A., and Cavalli, G. (2012). Three-dimensional folding and functional organization principles of the Drosophila genome. Cell 148, 458-472.

Simon, J.A., and Kingston, R.E. (2009). Mechanisms of polycomb gene silencing: knowns and unknowns. Nat. Rev. Mol. Cell Biol. 10, 697-708.

Simon, J.A., and Kingston, R.E. (2013). Occupying chromatin: Polycomb mechanisms for getting to genomic targets, stopping transcriptional traffic, and staying put. Mol. Cell 49, 808-824.

Simon, J., Chiang, A., and Bender, W. (1992). Ten different Polycomb group genes are required for spatial control of the abdA and AbdB homeotic products. Development 114, 493-505.

Sing, A., Pannell, D., Karaiskakis, A., Sturgeon, K., Djabali, M., Ellis, J., Lipshitz, H.D., and Cordes, S.P. (2009). A vertebrate Polycomb response element governs segmentation of the posterior hindbrain. Cell 138, 885-897.

Smalle, J., and Vierstra, R.D. (2004). The ubiquitin 26 S proteasome proteolytic pathway. Ann. Rev. Plant Biol. 55, 555-590.

Soppe, W.J., Bentsink, L., and Koornneef, M. (1999). The earlyflowering mutant efs is involved in the autonomous promotion pathway of Arabidopsis thaliana. Development 126, 4763-4770.

Soto, M.C., Chou, T.B., and Bender, W. (1995). Comparison of germline mosaics of genes in the Polycomb group of Drosophila melanogaster. Genetics 140, 231-243.

Steffen, P.A., and Ringrose, L. (2014). What are memories made of? How Polycomb and Trithorax proteins mediate epigenetic memory. Nat. Rev. Mol. Cell Biol. 15, 340-356.

Stone, S.L., Kwong, L.W., Yee, K.M., Pelletier, J., Lepiniec, L., Fischer, R.L., Goldberg, R.B., and Harada, J.J. (2001). LEAFY COTYLEDON2 encodes a B3 domain transcription factor that induces embryo development. Proc. Natl. Acad. Sci. USA 98, 11806-11811.

Struhl, G., and Akam, M. (1985). Altered distributions of Ultrabithorax transcripts in extra sex combs mutant embryos of Drosophila. EMBO J. 4, 3259-3264

Sun, B., Xu, Y., Ng, K.H., and Ito, T. (2009). A timing mechanism for stem cell maintenance and differentiation in the Arabidopsis floral meristem. Genes Dev. 23, 1791-1804.

Sun, B., Looi, L.S., Guo, S., He, Z., Gan, E.S., Huang, J., Xu, Y., Wee, W.Y., and Ito, T. (2014). Timing mechanism dependent on cell division is invoked by Polycomb eviction in plant stem cells. Science 343, 1248559.

Sung, S., and Amasino, R.M. (2004). Vernalization in Arabidopsis thaliana is mediated by the PHD finger protein VIN3. Nature 427, 159-164.

Sung, S., He, Y., Eshoo, T.W., Tamada, Y., Johnson, L., Nakahigashi, K., Goto, K., Jacobsen, S.E., and Amasino, R.M. (2006). Epigenetic maintenance of the vernalized state in Arabidopsis thaliana requires LIKE HETEROCHROMATIN PROTEIN 1. Nat. Genet. 38, 706-710.

Suzuki, M., Wang, H.H., and McCarty, D.R. (2007). Repression of the LEAFY COTYLEDON 1/B3 regulatory network in plant embryo development by VP1/ABSCISIC ACID INSENSITIVE 3LIKE B3 genes. Plant Physiol. 143, 902-911.

Swiezewski, S., Liu, F., Magusin, A., and Dean, C. (2009). Coldinduced silencing by long antisense transcripts of an Arabidopsis Polycomb target. Nature 462, 799-802.

Tamada, Y., Yun, J.Y., Woo, S.C., and Amasino, R.M. (2009). ARABIDOPSIS TRITHORAX-RELATED7 is required for methylation of lysine 4 of histone $\mathrm{H} 3$ and for transcriptional activation of FLOWERING LOCUS C. Plant Cell 21, 3257-3269.

Tang, X., Lim, M.H., Pelletier, J., Tang, M., Nguyen, V., Keller, W.A., Tsang, E.W., Wang, A., Rothstein, S.J., Harada, J.J., et al. (2012) Synergistic repression of the embryonic programme by SET DOMAIN GROUP 8 and EMBRYONIC FLOWER 2 in 
Arabidopsis seedlings. J. Exp. Bot. 63, 1391-1404

Tie, F., Banerjee, R., Stratton, C.A., Prasad-Sinha, J., Stepanik, V., Zlobin, A., Diaz, M.O., Scacheri, P.C., and Harte, P.J. (2009) CBP-mediated acetylation of histone $\mathrm{H} 3$ lysine 27 antagonizes Drosophila Polycomb silencing. Development 136, 3131-3141.

Tie, F., Banerjee, R., Saiakhova, A.R., Howard, B., Monteith, K.E. Scacheri, P.C., Cosgrove, M.S., and Harte, P.J. (2014). Trithorax monomethylates histone $\mathrm{H} 3 \mathrm{~K} 4$ and interacts directly with CBP to promote H3K27 acetylation and antagonize Polycomb silencing. Development 141, 1129-1139.

Tripoulas, N.A., Hersperger, E., La Jeunesse, D., and Shearn, A. (1994). Molecular genetic analysis of the Drosophila melanogaster gene absent, small or homeotic discs1 (ash1) Genetics 137, 1027-1038.

Turck, F., Roudier, F., Farrona, S., Martin-Magniette, M.L., Guillaume, E., Buisine, N., Gagnot, S., Martienssen, R.A. Coupland, G., and Colot, V. (2007). Arabidopsis TFL2/LHP1 specifically associates with genes marked by trimethylation of histone H3 lysine 27. PLoS Genet. 3, e86.

Wang, H., Wang, L., Erdjument-Bromage, H., Vidal, M., Tempst, P., Jones, R.S., and Zhang, Y. (2004). Role of histone H2A ubiquitination in Polycomb silencing. Nature 431, 873-878.

Wang, K.C., and Chang, H.Y. (2011). Molecular mechanisms of long noncoding RNAs. Mol. Cell 43, 904-914.

Wang, H., Chung, P.J., Liu, J., Jang, I.C., Kean, M.J., Xu, J., and Chua, N.H. (2014a). Genome-wide identification of long noncoding natural antisense transcripts and their responses to light in Arabidopsis. Genome Res. 24, 444-453.

Wang, Y., Fan, X., Lin, F., He, G., Terzaghi, W., Zhu, D., and Deng, X.W. (2014b). Arabidopsis noncoding RNA mediates control of photomorphogenesis by red light. Proc. Natl. Acad. Sci. USA 111, 10359-10364.

Wang, Z.W., Wu, Z., Raitskin, O., Sun, Q., and Dean, C. (2014c) Antisense-mediated FLC transcriptional repression requires the P-TEFb transcription elongation factor. Proc. Natl. Acad. Sci. USA 111, 7468-7473.

Weake, V.M., and Workman, J.L. (2008). Histone ubiquitination triggering gene activity. Mol. Cell 29, 653-663.

Weinhofer, I., Hehenberger, E., Roszak, P., Hennig, L., and Kohler, C. (2010). H3K27me3 profiling of the endosperm implies exclusion of polycomb group protein targeting by DNA methylation. PLoS Genet. 6 .

Woo, C.J., Kharchenko, P.V., Daheron, L., Park, P.J., and Kingston,
R.E. (2010). A region of the human HOXD cluster that confers polycomb-group responsiveness. Cell 140, 99-110.

Xu, L., and Shen, W.H. (2008). Polycomb silencing of KNOX genes confines shoot stem cell niches in Arabidopsis. Curr. Biol. 18, 1966-1971.

Yang, C., Bratzel, F., Hohmann, N., Koch, M., Turck, F., and Calonje, M. (2013). VAL- and AtBMI1-mediated H2Aub initiate the switch from embryonic to postgerminative growth in Arabidopsis. Curr. Biol. 23, 1324-1329.

Yang, H., Howard, M., and Dean, C. (2014a). Antagonistic roles for H3K36me3 and H3K27me3 in the cold-induced epigenetic switch at Arabidopsis FLC. Curr. Biol. 24, 1793-1797.

Yang, Y.W., Flynn, R.A., Chen, Y., Qu, K., Wan, B., Wang, K.C., Lei, M., and Chang, H.Y. (2014b). Essential role of IncRNA binding for WDR5 maintenance of active chromatin and embryonic stem cell pluripotency. eLife 3, e02046.

Yuan, W., Xu, M., Huang, C., Liu, N., Chen, S., and Zhu, B. (2011). H3K36 methylation antagonizes PRC2-mediated H3K27 methylation. J. Biol. Chem. 286, 7983-7989.

Yun, J.Y., Tamada, Y., Kang, Y.E., and Amasino, R.M. (2012). ARABIDOPSIS TRITHORAX-RELATED3/SET DOMAIN GROUP2 is required for the winter-annual habit of Arabidopsis thaliana. Plant Cell Physiol. 53, 834-846.

Zhang, X., Germann, S., Blus, B.J., Khorasanizadeh, S., Gaudin, V., and Jacobsen, S.E. (2007). The Arabidopsis LHP1 protein colocalizes with histone H3 Lys27 trimethylation. Nat. Struct. Mol. Biol. 14, 869-871.

Zhang, X., Bernatavichute, Y.V., Cokus, S., Pellegrini, M., and Jacobsen, S.E. (2009). Genome-wide analysis of mono-, di- and trimethylation of histone $\mathrm{H} 3$ lysine 4 in Arabidopsis thaliana. Genome Biol. 10, R62.

Zhao, Z., Yu, Y., Meyer, D., Wu, C., and Shen, W.H. (2005) Prevention of early flowering by expression of FLOWERING LOCUS C requires methylation of histone H3 K36. Nat. Cell Biol. $7,1256-1260$

Zhao, J., Sun, B.K., Erwin, J.A., Song, J.J., and Lee, J.T. (2008). Polycomb proteins targeted by a short repeat RNA to the mouse $X$ chromosome. Science 322, 750-756.

Zhao, J., Ohsumi, T.K., Kung, J.T., Ogawa, Y., Grau, D.J., Sarma, K. Song, J.J., Kingston, R.E., Borowsky, M., and Lee, J.T. (2010) Genome-wide identification of polycomb-associated RNAs by RIP-seq. Mol. Cell 40, 939-953. 